\title{
Energy requirements of antarctic sledge dogs
}

\author{
BY I. T. CAMPBELL* AND J. DONALDSON
}

British Antarctic Survey

(Received 12 June 1980 - Accepted 7 July 1980)

1. Eighteen male sledge dogs were weighed immediately on removal from their sheltered winter quarters at Halley Bay, Antaretica $\left(75^{\circ} 31^{\prime} \mathrm{s}, 26^{\circ} 42^{\circ} \mathrm{W}\right.$ ) and weekly thereafter for 14 weeks. The first 2 weeks they were tethered and inactive and the following 12 woeks travelled an average of $10.9 \mathrm{~km} / \mathrm{d}$ fully laden. Daily energy intake during winter and while tethered averaged $18-25 \mathrm{MJ} / \mathrm{d}$ and while travelling $13.9 \mathrm{MJ} / \mathrm{d}$.

2. Mean weight loss during the 2 weeks of inactivity was $2.3 \mathrm{~kg}$ despite an energy intake almost twice the recommended requirement. During the 12 weeks travelling energy intake decreased to $13.9 \mathrm{MJ} / \mathrm{d}$ but the weight loss stopped. Weather conditions at this time were becoming progressively milder.

3. The evidence suggests that sledge dogs are capable of high levels of cold-induced and possibly diet-induced thermogenesis and that these factors, particularly the former should be taken into account when designing dog rations and feeding schedules.

Dogs were introduced to the Antarctic in recent times in 1945-6 by the then Falkland Islands Dependencies Survey and, despite the increasing use of motorized vehicles have, until very recently been the principal method of transport of the British Antarctic Survey. Ideas of feeding have changed over the years and have been reviewed by Orr (1965). It has been shown that an energy intake of $10.5 \mathrm{MJ} / \mathrm{d}$ is barely sufficient to maintain the weight of tethered, resting dogs and for dogs travelling hard $(32.2 \mathrm{~km} / \mathrm{d})$ intakes of approximately $21 \mathrm{MJ} / \mathrm{d}$ are required (Wyatt, 1963; Orr, 1966). Recent feeding practice has been to give each dog 2-3 kg seal meat on alternate days while at base camp and Nutrican (Bob Martins Ltd) in the field (one $0.45 \mathrm{~kg}$ block daily and two blocks every third day). Nutrican is based on fish meal and each $0.45 \mathrm{~kg}$ block provides $10.5 \mathrm{MJ}(\mathrm{g} / \mathrm{kg} ; 250$ protein, 450 fat and 210 carbohydrate).

The effectiveness of this regimen has been studied by observing the weight changes occurring in dogs fed accordingly during the spring and summer of 1972 at Halley Bay, Antarctica $\left(75^{\circ} 31^{\prime} . \mathrm{S}, 26^{\circ} 42^{\prime} \mathrm{W}\right)$.

\section{MATERIALS AND METHODS}

Eighteen male husky dogs making up two sledge teams, were used. During the latter half of winter and early spring (early June-early September) they were kept tethered in a tunnel dug out of the snow approximately $7.6 \mathrm{~m}$ below the surface. The tunnel was open to the outside atmosphere via two ventilation shafts. There was no form of heating so, although providing shelter from wind and drift, the temperature in the tunnel was similar to the outside air temperature.

The dogs were removed from the tunnel at the end of the first week in September and for the following 2 weeks were tethered, on the surface, with chains approximately $2 \mathrm{~m}$ long. They were fed the same diet as during winter, $2-3 \mathrm{~kg}$ seal meat with blubber on alternate days. The first week they took no exercise and during the second week participated in two short training runs with lightly-laden sledges.

At the end of the second week both teams left base camp and spent 12 weeks in the field

- Present address: University Department of Anaesthesia, Royal Liverpool Hospital, Prescot Street, P.O. Box 147, Liverpool L69 3BX. 
Table 1. Mean weekly temperatures $\left(^{\circ}\right)$, wind speed $(\mathrm{m} / \mathrm{s})$ and chill factor* to which Antarctic sledge dogs were exposed

\begin{tabular}{lccc}
\hline \multicolumn{1}{c}{ Date } & $\begin{array}{c}\text { Mean } \\
\text { temperature }\end{array}$ & $\begin{array}{c}\text { Mean wind } \\
\text { speed }\end{array}$ & $\begin{array}{c}\text { Chill } \\
\text { factor }\end{array}$ \\
\hline 26 Aug to 2 Sept & $-31 \cdot 2$ & - & 674 \\
2-9 Sept & $-28 \cdot 5$ & - & 645 \\
9-16 Sept & $-27 \cdot 6$ & $6 \cdot 5$ & 1787 \\
16-23 Sept & $-29 \cdot 4$ & $5 \cdot 9$ & 1801 \\
23-30 Sept & $-27 \cdot 2$ & $7 \cdot 5$ & 1827 \\
30 Sept to 7 Oct & $-27 \cdot 7$ & $5 \cdot 0$ & 1690 \\
7-14 Oct & $-29 \cdot 4$ & $3 \cdot 7$ & 1625 \\
14-21 Oct & $-24 \cdot 4$ & $5 \cdot 8$ & 1665 \\
21-28 Oct & $-20 \cdot 3$ & $7 \cdot 6$ & 1625 \\
28 Oct to 4 Nov & $-13 \cdot 4$ & $7 \cdot 3$ & 1400 \\
4-11 Nov & $-15 \cdot 4$ & $7 \cdot 2$ & 1459 \\
11-18 Nov & $-11 \cdot 7$ & $9 \cdot 0$ & 1410 \\
18-25 Nov & $-10 \cdot 3$ & $5 \cdot 3$ & 1222 \\
25 Nov to 2 Dec. & $-6 \cdot 1$ & $5 \cdot 8$ & 1124 \\
2-9 Dec & $-6 \cdot 6$ & $9 \cdot 2$ & 1253 \\
9-16 Dec & $-6 \cdot 8$ & $4 \cdot 3$ & 1070 \\
\hline \hline
\end{tabular}

* Derived from the formula of Siple and Passel (1945).

Table 2. Summary of feeding and activity regimens of two dog teams at Halley Bay, Antarctica in 1972

\begin{tabular}{|c|c|c|c|}
\hline Period & Duration & Food offered $(\mathrm{kg} / \mathrm{d})$ & Housing/activity \\
\hline $\begin{array}{l}\text { Winter } \\
9-16 \text { Sept } \\
16-23 \text { Sept }\end{array}$ & $\left.\begin{array}{l}4 \text { months } \\
1 \text { week } \\
1 \text { week }\end{array}\right\}$ & $1-1.5$ seal meat & $\begin{array}{l}\text { Snow tunnel } \\
\text { Surface/tethered } \\
\text { Surface/tethered } \\
2 \text { training runs }\end{array}$ \\
\hline 23 Sept to 16 Dec & 12 weeks & 0.6 Nutrican & $\begin{array}{l}\text { Travelling average } \\
10.9 \mathrm{~km} / \mathrm{d} \text { fully } \\
\text { laden sledges }\end{array}$ \\
\hline
\end{tabular}

travelling over gently-undulating ice-shelf, most of the time fully laden. Supplies were obtained from a depot and the total distance travelled was $932.4 \mathrm{~km}$, an average of $10.9 \mathrm{~km} / \mathrm{d}$. The meteorological conditions to which the dogs were exposed during this time, mean weekly temperature and wind speed, are given in Table 1 along with the derived 'chill factor' (Siple \& Passel,1945). For the entire period in the field the dogs were fed one $0.45 \mathrm{~kg}$ Nutrican block daily and every third day they received two blocks. Activity and feeding regimens are summarized in Table 2.

All dogs were weighed immediately on removal from the tunnel and weekly thereafter for 14 weeks ( 2 weeks at base and 12 weeks travelling). They were weighed to the nearest $0.1 \mathrm{~kg}$ using a spring balance suspended from a tripod.

\section{RESULTS}

The mean ( \pm SE) body-weight of all eighteen dogs on a weekly basis is shown in Fig. 1. Mean weight on removal from the tunnel was $40.2 \mathrm{~kg}$. This fell to $39.0 \mathrm{~kg}$ after 1 week on the surface and to $37.9 \mathrm{~kg}$ at the end of the second week, a drop of $2.3 \mathrm{~kg}$ which was statistically 


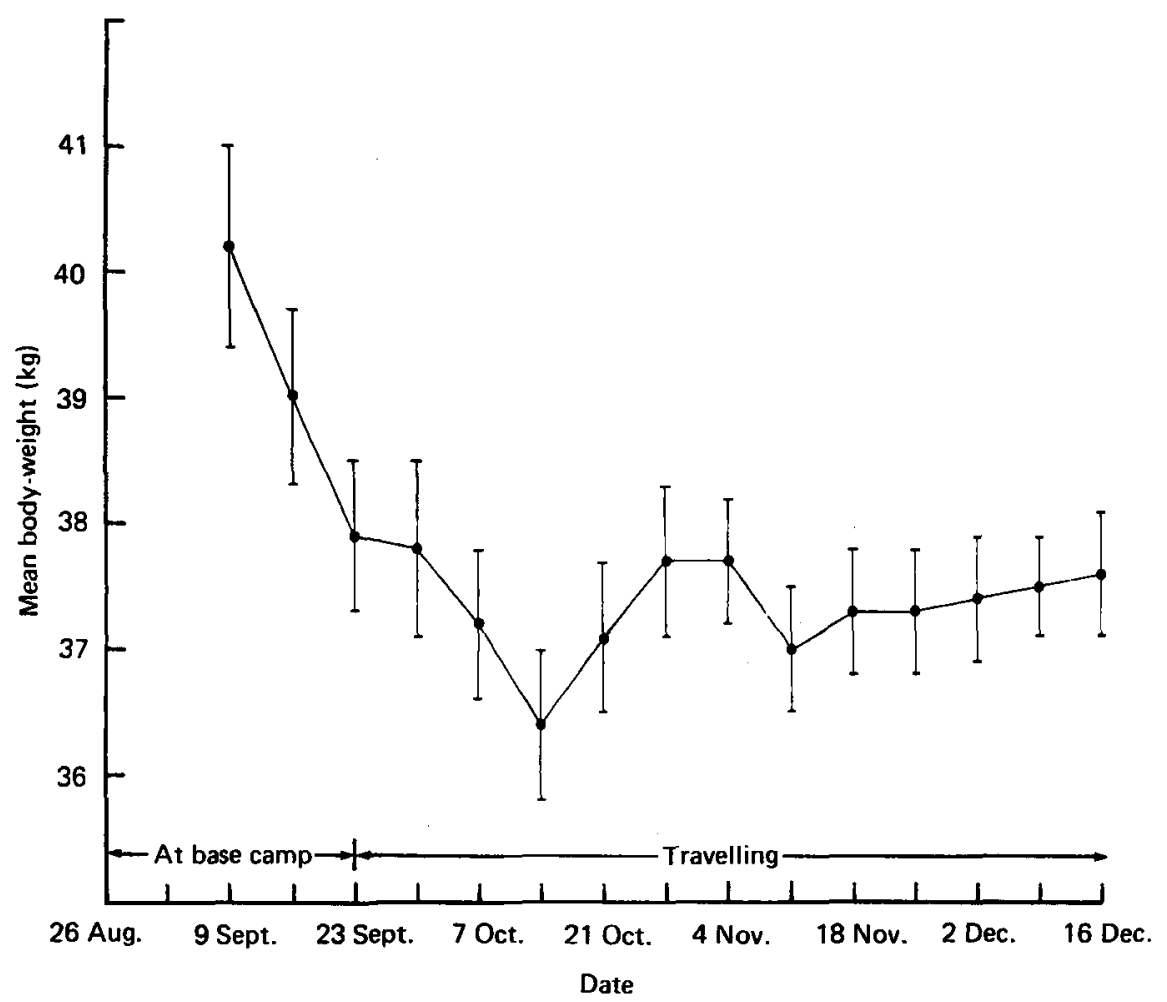

Fig. 1. Mean body-weight of eighteen male sledge dogs immediately on removal from winter quarters and during the spring and summer travelling season. Vertical bars represent standard errors.

significant $(P<0.025$, paired $t$-test). The lowest weight recorded was $36.4 \mathrm{~kg}$ after 3 weeks in the field. This was significantly different from the $37.9 \mathrm{~kg}$ observed just before the dogs left base camp $(P<0.05)$ but subsequently the mean body-weight rose and, apart from the previously-mentioned week, was between 37.0 and $37.8 \mathrm{~kg}$ for the entire time spent travelling.

\section{Discussion}

From the fact that the mean weight of the dogs altered very little during the 12 weeks travelling it would appear that the diet they were given (four blocks of Nutrican during each $3 \mathrm{~d}$ period, providing an average of $13.9 \mathrm{MJ} / \mathrm{d}$ ) was adequate for their needs in these circumstances. What is of interest is that the greatest drop in weight occurred in the first 2 weeks when they were chained on the surface, took very little exercise and were given the same seal-meat diet they had received in the tunnel. Mean temperature during the 2 weeks was $-28.4^{\circ}$.

Seal meat with blubber is said to contain $18 \cdot 1 \mathrm{MJ} / \mathrm{kg}$ although lean seal meat contains only $4.7 \mathrm{MJ} / \mathrm{kg}$ (Wyatt, 1963). Thus a dog given 2-3 kg meat with blubber on alternate days, would on average be receiving between 18 and $25 \mathrm{MJ} / \mathrm{d}$. This is considerably greater than the $13.9 \mathrm{MJ} / \mathrm{d}$ received in the field and similar to the requirement of $21 \mathrm{MJ} / \mathrm{d}$ for hard travelling (Orr, 1966) yet tethered, inactive dogs lost weight.

The recommended energy intake for weight maintenance of dogs in temperate environments is $552 \mathrm{~kJ} / \mathrm{kg}$ body-weight ${ }^{0.75}$ (National Research Council, 1974). Durrer \& Hannon (1962) found a mean intake of $856 \mathrm{~kJ} / \mathrm{kg}$ body-weight ${ }^{0 \cdot 75}$ for Alaskan Huskies at temperatures 
of $-17^{\circ}$ and demonstrated a significant negative correlation between energy intake measured over 1 month and mean monthly temperature. Orr (1966) found the minimum maintenance requirements for tethered dogs in Antarctica was $698 \mathrm{~kJ} / \mathrm{kg}$ body-weight $\mathrm{t}^{0.75}$. He did not state the environmental conditions when these measurements were made, but they were performed at a latitude of $63^{\circ} \mathrm{S}$ at the end of January when the temperature would have been approximately $0-10^{\circ}$. The $21 \mathrm{MJ} / \mathrm{d}$ nominally provided by the seal-meat ration represents a daily intake of $1340 \mathrm{~kJ} / \mathrm{kg}$ body-weight ${ }^{0.75}$.

During their time in the tunnel the dogs were exposed to temperatures close to the outside temperature but protected from wind and drift. The diet was exactly the same after their removal from the tunnel as it had been for the previous 4 months. During their first 2 weeks on the surface mean weight loss was $2.3 \mathrm{~kg}$. If this loss were assumed to be fat, as it probably would be in healthy animals, this represents an increase in energy expenditure of $6.3 \mathrm{MJ} / \mathrm{d}$ or $392 \mathrm{~kJ} / \mathrm{kg}$ body-weight ${ }^{0.75}$ and, with a dietary intake of $1340 \mathrm{~kJ} / \mathrm{kg}$ body-weight ${ }^{0.75}$ suggests that total energy expenditure was $1730 \mathrm{~kJ} / \mathrm{kg}$ body-weight ${ }^{0 \cdot 75}$.

The most obvious explanation for this weight loss and apparent increase in metabolic rate was an increase in energy demand secondary to the chilling effect of wind and drifting snow, a finding consistent with the work of Durrer \& Hannon (1962). It is perhaps surprising that this extent of weight loss should occur when intake was theoretically twice the requirement. Both human subjects and rats who are chronically consuming energy in excess of their needs are thought to be capable of metabolizing most of the excess (Miller et al. 1967; Rothwell \& Stock, 1979). If this were occurring while the dogs were in the tunnel the sudden exposure to wind and drifting snow on their removal must have presented an additional thermoregulatory stress, leading to even greater rates of heat production and consequent weight loss even though by conventional standards the energy supply was more than adequate for weight maintenance.

Weight loss continued for 3 weeks after travelling started and then stopped, despite a change to the Nutrican diet and a lower mean energy intake of $13.9 \mathrm{MJ} / \mathrm{d}$. Possible reasons for this finding are that over this period either the dogs' thermogenic mechanisms re-adjusted to the lower intake or that as the environmental temperature increased (Table 1) the demands made on these mechanisms decreased. The correlation coefficient of mean weekly chill factor and mean change in body-weight each week was 0.436 , but was not significant $(0.1>P>0.05)$.

The pattern of weight change described in this study suggests that the sledge dog is capable of high levels of cold-induced and perhaps diet-induced thermogenesis. This should be taken into account when designing and assessing the adequacy of dog rations.

The authors are grateful to Drs Peter Kendal, Ronald Anderson and Michael Stock for their help and to Miss Jean Wilson for secretarial assistance.

\section{REFERENCES}

Durrer, J. L. \& Hannon, J. P. (1962). Am. J. Physiol. 202, 375.

Miller, D. S., Mumford, P. \& Stock, M. J. (1967). Am. J. clin. Nutr. 20, 1223.

National Research Council (1974). Nutrient Requirements of Domestic Animals no. 8, Nutrient Requirements of Dogs. Washington, DC: National Academy of Sciences.

Orr, N. W. M. (1965). Br. Ant. Surv. Bull. 7, 53.

Orr, N. W. M. (1966). Br. J. Nutr. 20, 1.

Rothwell, N. J. \& Stock, M. J. (1979). Nature, New Biol. $281,31$.

Siple, P. A. \& Passel, C. F. (1945). Proc. Am. Phil. Soc. 89, 177.

Wyatt, H. T. (1963). Br. J. Nutr. 17, 273. 